\title{
SPLETNA SLOVENŠČINA POD DROBNOGLEDOM DIJAKOV IN ŠTUDENTOV
}

\section{Špela ARHAR HOLDT}

Zavod za uporabno slovenistiko Trojina

Filozofska fakulteta Univerze v Ljubljani

Arhar Holdt, Š. (2016): Spletna slovenščina pod drobnogledom dijakov in študentov. Slovenščina 2.O, 4 (2): 128-131.

URL: http://www.trojina.org/slovenscina2.o/arhiv/2016/2/Slo2.o_2016_2_o6.pdf.

\section{ORGANIZACIJSKI OKVIR}

V tednu med 4. in 8. julijem 2016 je pod okriljem Oddelka za prevajalstvo Filozofske fakultete Univerze $\mathrm{v}$ Ljubljani in s finančno podporo slovenske raziskovalne infrastrukture Clarin.si potekal jezikoslovni raziskovalni tabor za dijake in študente. Tabor, katerega osrednja tema je bila spletna slovenščina, je bil letos že drugi po vrsti (poročilo o prvem v Fišer 2015), za razliko od lanskega leta, ko so bili njegovi udeleženci le dijaki, pa je tokrat vključeval tudi študente. Študentski in dijaški program je bil ločen in je potekal za oboje vzporedno. Obe ravni programa sta bili sestavljeni iz predavanj, na katerih so udeleženci spoznali nove vsebine, in delavniškega dela, v katerem so usvojena znanja prenesli v lastno raziskovalno prakso. Preplet obeh programov je bil zasnovan in izpeljan pod organizacijsko taktirko doc. dr. Darje Fišer in asist. Jaka Čibeja, ob pomoči Dafne Marko, Ize Škrjanec in Katje Zupan, in sicer kot ena od aktivnosti projekta Jezikoslovna analiza nestandardne slovenščine.

\section{SREDNJES̆OLSKI RAZISKOVALNI TABOR}

Glavni namen srednješolskega tabora je bil seznaniti dijake z osnovnimi koncepti korpusnega jezikoslovja in jim ponuditi možnost, da ob spoznavanju sodobnih jezikoslovnih vprašanj oblikujejo in izražajo mnenja o jeziku oz. jezikovni rabi. Dijaška skupina je prek tedna spoznala pet različnih korpusnojezikoslovnih tem, v delavnicah pa so se naučili dela s korpusi Gigafida, Gos, Janes in Šolar. V ponedeljek sem dr. Špela Arhar Holdt 
predstavila uvod v korpusno jezikoslovje, na katerem smo spoznali, kaj je korpus, kako in čemu korpuse gradimo ter kako ustrezno interpretirati korpusne podatke. V torek je dr. Damjan Popič predaval o razmerju med koncepti spletne in standardne slovenščine in pri tem razbijal mit, da pojav spletne slovenščine vodi v propad jezika. V sredo je dr. Polona Gantar predstavila raziskovalno področje in izzive frazeologije, s poudarkom na frazeologiji spletnega jezika, ki je (npr. na Twitterju) pogosto zelo duhovita in domiselna. V četrtek je dr. Tadeja Rozman razložila, kako v spletnem komuniciranju prvine govorjenega jezika prehajajo $\mathrm{v}$ pisnega, pa tudi, da se slednje dogaja redkeje in drugače, kot nam govori jezikovna intuicija. Teden je strnil asist. Jaka Čibej, ki je na primerih iz spletnega gradiva predstavil stik slovenščine z drugimi jeziki, predvsem značilnosti prevzemanja tujejezičnih prvin in medjezikovnega preklapljanja. Gradiva predavanj in vaj so dostopna na spletni strani: http://nl.ijs.si/janes/dogodki/tabor-2016/.

Dijaki (tabora se jih je udeležilo 21) so se izkazali za odzivne in sproščene sogovornike, ki so presenečali ne le s hitrostjo usvajanja novih pojmov in tehničnih spretnosti, ampak tudi z zrelim pogledom na lastno jezikovno rabo in strpnim odnosom do jezikovne rabe drugih. S predavateljskega stališča je tako kot problem mogoče izpostaviti predvsem dejstvo, da večina udeležencev v resnici ni načrtovala oz. ne načrtuje vpisa na jezikoslovne študijske smeri; kljub temu pa so raziskovalni tabor v zaključni evalvaciji ocenili navdušeno pozitivno.

\section{3 ŠTUdENTSKA POLETNA ŠOLA}

Nadstropje više je sočasno s srednješolskim programom potekala poletna šola za študente. Med 14 udeleženci so bili po večini (ne pa izključno) študentje jezikoslovnih smeri: slovenistike, prevajalstva in drugih jezikov. V primerjavi z dijaškim programom je študentski ponujal nekoliko večjo raznolikost vsebin, manj pa je bilo uvajanja v delo s konkretnimi korpusi; tako kot dijaki pa so tudi študentje zadnji del vsakega dneva posvetili samostojnemu raziskovanju izbranih jezikoslovnih vprašanj. Študentski del programa je otvorila dr. Darja Fišer, ki je predstavila projekt Janes in njegov glavni izdelek, obsežni in napredno označeni korpus računalniško posredovane slovenščine, pa tudi sorodne evropske projekte in raziskave, ki se posvečajo raziskovanju komuniciranja na spletu. Drugi dan sta predavala dr. Marko Stabej, ki je govoril 
o spreminjanju jezika skozi čas, in dr. Nataša Logar, ki je študente učila ustrezne interpretacije korpusnih podatkov. V sredo sta predavali dr. Tadeja Rozman, ki je predstavila korpus Šolar in možnosti povezovanja izsledkov iz tega vira z analizo podatkov v korpusu Janes, ter dr. Helena Dobrovoljc, ki se je osredotočila na vprašanja knjižnojezikovnega standarda in standardizacije skozi zgodovino ter v sedanjosti - po pojavu spletnega komuniciranja. V četrtek sta sledili predavanji dr. Mije Michelizza, ki je predstavila tipološko analizo spletnih besedil, in dr. Damjana Popiča, ki se je z duhovito izbranimi primeri dotaknil vprašanj jezika in spola. Zadnji dan sva predavali dr. Špela Arhar Holdt s pregledom obstoječih možnosti za skladenjsko analizo spletne slovenščine ter dr. Polona Gantar z vprašanji in odgovori s področja korpusne frazeologije. Gradiva predavanj in delavnic so dostopna na spletni strani: http://nl.ijs.si/janes/dogodki/poletna-sola-2016/.

\section{SKLEP}

Rezultate svojih raziskav so dijaki in študenti predstavili na skupnem dogodku ob zaključku poletne šole. Dijaške skupine so si izbrale naslednje teme: Govor in spletna slovenščina (Iza Tušar, Karmen Strel, Sonja Gabrijelčič, Melani Potrč in Tina Brezner); Pojavljanje lastnih imen v korpusih (Katarina Geč, Tajda Kralj, Blaž Šoba in Uroš Tesič); Raba kratic med mladimi (Anže Ros, Reja Žinko, Anja Marton in Sebastjan Krek); Raba latinskih izrekov v spletni in splošni slovenščini (Jana Frank, Maša Jambriško, Nika Lorber in Jasna Reščič); Pozitivno in negativno besedišče v korpusih Kres in Janes (Julijana Zupanič, Katja Predan, Luka Černe in Lucija Gruden). Študenti so se odločali predvsem za sociolingvistično obarvano tematiko: Žaljivke korporativno in privat (Eva Cimerman, Miha Helbl in Krištof Brezar); Feminativi (Maja Kovač, Aleksandra Rajković in Angelika Zimmermann); Kako tvitajo moški in ženske? (Zoran Fijavž, Tajda Kolšek in Polona Polc); Kako moški in ženske uporabljajo kletvice na Twitterju? (Janik Ježovnik in Luka Luštek). Prispevek Glagolske oblike -jo/-do v korpusu Kres, tvitih in blogih (Dafne Marko, Gašper Pesek in Iza Škrjanec) je bil izbran za najboljšega in bo predstavljen na študentski sekciji četrte mednarodne konference o računalniško posredovani komunikaciji in korpusih družbenih omrežij (4th Conference on CMC and Social Media Corpora for the Humanities), ki bo septembra potekala v Ljubljani. 
Zaradi časovnih omejitev so bile predstavljene raziskave metodološko precej osnovne, v sklepih mestoma nekoliko preuranjene, vendar so predstavitve odražale porast znanja pri udeležencih, odpirale relevantne razmisleke in izhodišča za nadaljnje raziskave, zato smo bili predavatelji z rezultati zadovoljni. Pozitivne ocene udeležencev in predavateljev nakazujejo, da bi bilo s tovrstnimi pobudami smiselno nadaljevati, še zlasti, ker na področju jezikoslovja izrazito manjka dogodkov, ki bi mladim omogočali, da spoznajo potencialne bodoče študijske teme in okolje. Vsekakor pa bi bilo za v bodoče (predvsem na ravni študentskega programa) nujno razmisliti, katere od ponujenih vsebin so dodatne oz. interesne, katere pa so temeljne in bi jih bilo treba $\mathrm{v}$ resnici vključiti $\mathrm{v}$ redne študijske programe. Bilo bi namreč kontraproduktivno (malo pa tudi fakultetna lažna reklama), če bi se navadili srečevanje s sodobnimi jeziko(slo)vnimi viri in metodami - puščati za poletje.

\section{LITERATURA}

Fišer, D. (2015): Raziskovalni tabor spletne slovenščine za srednješolce JANES. Slovenščina 2.03 (1): 59-61.

To delo je ponujeno pod licenco Creative Commons: Priznanje avtorstvaDeljenje pod enakimi pogoji 4.o Slovenija.

This work is licensed under the Creative Commons Attribution ShareAlike 4.0 License Slovenia.

\section{http://creativecommons.org/licenses/by/4.o/}

$$
\text { (c) () () }
$$

